\title{
Pengendalian Internal, Budaya Organisasi, dan Kecenderungan Kecurangan Akuntansi di LPD Kabupaten Tabanan
}

\author{
Ni Luh Gede Dandy Adi Pratiwi ${ }^{1}$ \\ Fakultas Ekonomi dan Bisnis \\ Universitas Udayana, Indonesia
}

\author{
I Gusti Ayu Nyoman Budiasih 2 \\ Fakultas Ekonomi dan Bisnis \\ Universitas Udayana, Indonesia
}

\begin{abstract}
Surel : pratiwidandy@gmail.com
ABSTRAK

Penelitian ini bertujuan untuk memeroleh bukti empiris mengenai pengaruh pengendalian internal dan budaya organisasi pada kecenderungan kecurangan akuntansi di LPD Kabupaten Tabanan. Dipilihnya LPD Kabupaten Tabanan dalam penelitian ini karena adanya fenomena kecurangan yang terjadi di beberapa LPD Kabupaten Tabanan. Regresi liniear berganda merupakan teknik analisis data yang digunakan dalam penelitian ini. Didapatkan hasil bahwa pengendalian internal dan budaya organisasi berpengaruh negatif pada kecenderungan kecurangan akuntansi di Lembaga Perkreditan Desa Kabupaten Tabanan. Penelitian ini dapat mendukung teori fraud triangle sebagai implikasi penelitian secara teoritis. Penelitian ini dapat memberi masukan untuk meningkatkan pengendalian internal, budaya organisasi dan mengurangi kecurangan yang dilakukan oleh pihak internal LPD sebagai implikasi penelitian secara praktis.
\end{abstract}

Kata Kunci: Kecenderungan Kecurangan Akuntansi; Pengendalian Internal; Budaya Organisasi.

\section{Internal Control, Organizational Culture, and the Tendency of Accounting Fraud in LPD Tabanan Regency}

\begin{abstract}
This study aims to obtain empirical evidence regarding the influence of internal control and organizational culture on the tendency of accounting fraud in LPD Tabanan Regency. Tabanan Regency LPD was chosen in this study because of the phenomenon of fraud that occurred in several Tabanan Regency LPDs. Multiple linear regression is a data analysis technique used in this study. The results show that internal control and organizational culture negatively affect the tendency of accounting fraud in Tabanan Village Credit Institutions. This research can support the theory of fraud triangle as a theoretical implication of research. This research can provide input to improve internal control, organizational culture and reduce fraud committed by internal LPD parties as a practical research implication.
\end{abstract}

Keywords: $\quad$ Tendency of Accounting Fraud; Internal Control; Organizational Culture.

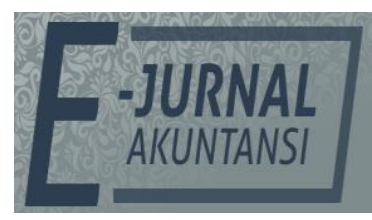

e-ISSN 2302-8556

Vol. 30 No. 11

Denpasar, Nopember 2020

Hal. 2907-2921

DOI:

10.24843/EJA.2020.v30.i11.p15

PENGUTIPAN:

Pratiwi, N.L.G.D.A. \&

Budiasih, I G.A.N. (2020).

Pengendalian Internal,

Budaya Organisasi, dan Kecenderungan Kecurangan

Akuntansi di LPD

Kabupaten Tabanan. E-Jurnal Akuntansi, 30(11), 2907-2921

RIWAYAT ARTIKEL: Artikel Masuk: 15 Desember 2019 Artikel Diterima: 17 Januari 2020

Artikel dapat diakses : https://ojs.unud.ac.id/index.php/Akuntansi/index 


\section{PENDAHULUAN}

Pengambilan keputusan yang tepat dalam suatu organisasi didukung oleh informasi yang bersifat objektif dan terhindar dari unsur-unsur kecurangan. Kecurangan dapat diminimalisir dengan adanya budaya kejujuran, kode etik tinggi dalam suatu organisasi serta tindakan nyata untuk mengurangi kecurangan yang dapat merugikan organisasi pada khususnya dan masyarakat pada umumnya (Julyana, 2015). Informasi dalam laporan keuangan sangat penting dan disusun sesuai dengan standar akuntansi yang berlaku (Chandrayatna \& Sari, 2019). Kecurangan dapat terjadi di organisasi yang bergerak di bidang keuangan. Salah satu lembaga keuangan yang mengalami kasus kecurangan yaitu Lembaga Perkreditan Desa (LPD).

LPD merupakan badan usaha keuangan yang berfungsi sebagai tempat penyaluran kredit dan simpanan dalam bentuk tabungan untuk melayani masyarakat dalam meningkatkan perekonomian di desa setempat (Putra \& Latrini, 2018). Pertumbuhan LPD dalam mendorong pembangunan ekonomi desa didukung oleh sistem pengendalian yang baik dan peningkatan sumber daya manusia agar terhindar dari kecurangan yang dapat merugikan masyarakat. Kecurangan dapat mengikis tingkat kepercayaan dan menyebabkan kerugian yang bersifat finansial bagi suatu organisasi (Okoye \& Nwoka, 2019)

Tabel 1. Data Status Kesehatan LPD Se-Kabupaten Tabanan Tahun 2014-2018

\begin{tabular}{ccccccc}
\hline Tahun & Sehat & $\begin{array}{c}\text { Cukup } \\
\text { Sehat }\end{array}$ & $\begin{array}{c}\text { Kurang } \\
\text { Sehat }\end{array}$ & $\begin{array}{c}\text { Tidak } \\
\text { Sehat }\end{array}$ & Macet & $\begin{array}{c}\text { Tidak } \\
\text { Operasi }\end{array}$ \\
\hline 2014 & 208 & 20 & 15 & 64 & - & - \\
2015 & 203 & 27 & 16 & 61 & - & - \\
2016 & 198 & 26 & 22 & 61 & - & - \\
2017 & 181 & 38 & 24 & 5 & 58 & 1 \\
2018 & 183 & 38 & 24 & 4 & 56 & 2 \\
\hline
\end{tabular}

Sumber: LPLPD Kabupaten Tabanan, 2019

Berdasarkan laporan tingkat kesehatan LPD di Kabupaten Tabanan yang diperoleh dari LPLPD Kabupaten Tabanan menyatakan bahwa jumlah LPD di Kabupaten Tabanan yaitu sebanyak 304 LPD. Lembaga Perkreditan Desa (LPD) dengan kategori sehat dari tahun 2014-2018 mengalami penurunan dan peningkatan. Kategori LPD kurang sehat dari tahun 2014-2018 mengalami peningkatan. LPD dengan kategori tidak beroperasi pada tahun 2018 mengalami peningkatan dari tahun-tahun sebelumnya sebesar 0,65 persen.

Permasalahan yang terjadi di beberapa LPD Kabupaten Tabanan yaitu adanya kredit macet dan kecurangan yang dilakukan oleh pihak internal LPD. Permasalahan kredit macet menunjukan adanya sistem pengendalian internal yang lemah dan menyebabkan risiko kerugian bagi suatu organisasi (Dewi et al., 2017). Kasus kecurangan terjadi di LPD Belumbang pada tahun 2018, dana digunakan oleh tiga oknum pengurus LPD dengan nominal mencapai $\mathrm{Rp} 1,3$ miliar (balitribune.co.id). Kasus fraud di LPD Tabanan pada tahun 2018, dana diselengwengkan oleh oknum pengurus LPD dengan nominal mencapai Rp 1,2 miliar (baliexpress.co.id). Kasus fraud terjadi LPD Sunantaya. Penyalahgunaan dana nasabah di LPD ini mencapai $\mathrm{Rp}$ 1,4 miliar oleh ketua dan bagian pembukuan (balitribune.co.id). 
Umar et al., (2019) menyatakan kontrol internal secara langsung memengaruhi kualitas laporan keuangan pemerintah melalui pencegahan penipuan. Penelitian oleh Putra \& Latrini (2018) menunjukan pengendalian internal semakin ditingkatkan dalam suatu organisasi maka semakin kecil tingkat kecurangan yang terjadi di organisasi tersebut. Kecurangan yang terjadi disebabkan oleh pengendalian internal yang tidak diterapkan dengan benar sehingga dapat merugikan organisasi LPD (Indrijawati et al., 2019).

Pengendalian internal merupakan proses yang memberikan keyakinan terhadap suatu keandalan laporan keuangan sehingga tercapai efektivitas dan efisiensi dalam suatu organisasi (Julyana, 2015). Tindakan kecurangan dalam keuangan di suatu organisasi/pemerintah dapat dicegah melalui sistem pengendalian internal yang memadai (Atmadja \& Saputra, 2017). Udayani \& Sari (2017), Dewi et al (2017), Dewi \& Wirakusuma (2019) dan Chandrayatna \& Sari (2019) menyatakan pengendalian internal berpengaruh negatif pada kecenderungan kecurangan akuntansi.

Kecurangan akuntansi dapat diminimalisir oleh budaya organisasi yang kuat dalam suatu organisasi. Keuntungan baik secara individu maupun kelompok diperoleh dari adanya peluang yang muncul untuk berprilaku curang (Nurlaeliyah \& Anisykurlillah, 2017). Budaya dapat meningkatkan komitmen organisasional dan meningkatkan kinerja perusahaan yang diterapkan melalui program pelatihan etika kepada anggota yang ada di suatu organisasi (Omar et al., 2015). Budaya organisasi yang sehat dan kuat mendorong organisasi mencapai tujuan secara efektif (Ocansey \& Ganu, 2017). Anggota organisasi dipersatukan dengan persepsi bersama untuk melakukan tindakan dan memecahkan masalah serta membentuk suatu sistem melalui budaya organisasi (Aprilliyanti \& Fitri, 2018). Kecurangan dapat dicegah dengan adanya budaya organisasi yang baik, menjunjung tinggi nilai kejujuran, meningkatkan kualitas kerja dan taat terhadap aturan yang sudah diterapkan dalam suatu organisasi (Zelmiyanti \& Anita, 2015). Budaya yang kuat dapat diterapkan oleh karyawan sehingga tingkat kecurangan dapat diminimalisir (Arnila et al., 2018). Budaya organisasi dapat membentuk pemikiran anggota dalam organisasi untuk berperilaku etis dan mempunyai rasa ikut memiliki (sense of belonging) serta rasa bangga sebagai bagian dari organisasi (sense of identity). Lestari et al (2015) menyatakan penerapan budaya etis dalam organisasi dapat mendorong orangorang di dalam suatu organisasi untuk berperilaku etis sehingga peluang untuk melakukan kecurangan dapat diminimalisir. Berdasarkan hasil penelitian yang dilakukan oleh Putra \& Latrini (2018), Lestari et al (2015) menjelaskan budaya organisasi berpengaruh negatif terhadap kecenderungan kecurangan akuntansi.

Kecurangan didefinisikan sebagai suatu tindakan secara sengaja yang dilakukan oleh seseorang maupun kelompok yang dapat merugikan suatu entitas atau pihak lain. Pengendalian internal dan budaya organisasi yang kuat merupakan cara untuk meminimalisir kecurangan akuntansi. Pengendalian internal dan budaya organisasi yang baik dan kuat serta terhindar dari kecurangan merupakan wujud implementansi dari bidang ilmu Akuntansi Keperilakuan. Akuntansi keperilakuan merupakan subdisplin ilmu akuntansi yang melibatkan aspek-aspek keperilakuan manusia terkait dengan proses pengambilan keputusan ekonomi. Laporan keuangan harus terhindar dari unsur 
kecurangan baik itu manipulasi atau mengelabui laporan keuangan sehingga laporan keuangan yang dihasilkan yaitu laporan andal sebagai input dalam proses pengambilan keputusan dan dapat memberikan evaluasi kinerja terhadap unit atau kelompok di lingkungan organisasi (Lubis, 2009:13). Penipuan merupakan representasi yang keliru dari fakta material dalam pernyataan keuangan. Pernyataan salah dapat diarahkan kepada pihak luar organisasi seperti menutupi ketidakmampuan pihak internal, pencurian atau penggunaan dana yang tidak tepat dan penggunaan asset organisasi yang tidak benar oleh karyawan (Setiawan, 2018). Tindakan korupsi dapat diminimalisir dengan pelatihan dan pendidikan yang efektif serta memperbaiki kualitas kontrol internal akan menghasilkan manajemen yang bertanggungjawab, pekerja yang terampil dan sistem yang andal (Nahartyo \& Haryono, 2018). Pengendalian internal menurut Widilestariningtyas \& Karo (2016) merupakan suatu proses yang diterapkan dan dipercayakan guna mencapai tujuan dan strategi jangka panjang. Prinsip yang dipegang teguh oleh manajemen yaitu pentingnya suatu pengendalian internal diterapkan maka tindakan yang sesuai dengan nilai-nilai etika yang mengatur organisasi sesuai dengan prinsip integritas direspon oleh pihak lain (Rivera, 2018).

Fraud triangle theory dapat menjelaskan kecurangan. Kesempatan, tekanan, dan rasionalisasi merupakan faktor yang memengaruhi karyawan melakukan tindak kecurangan menurut fraud triangle theory. Hubungan kecurangan, pengendalian internal, dan budaya organisasi dengan teori fraud triangle yaitu seseorang melakukan kecurangan di suatu organisasi/instansi karena ada kesempatan yang muncul untuk melakukan kecurangan. Kesempatan muncul dalam organisasi karena lemahnya sistem pengendalian internal. Kesempatan peluang untuk melakukan penipuan didorong oleh beberapa sumber yaitu pengendalian internal yang buruk, kurangnya pelatihan terhadap karyawan di suatu organisasi dan lemahnya budaya organisasi (Said et al., 2017). Perusahaan harus memperbaiki sistem pengendalian internal, sistem pengawasan dan tugas wewenang yang efektif agar kesempatan oleh pelaku kecurangan dapat diminimalisir sehingga dengan adanya pengendalian internal maka dapat memantau kinerja aktual dan mewujudkan kelangsungan organisasi yang kompetitif (Laffin \& Gomes, 2013). Pengendalian internal merupakan siste kontrol yang sangat penting di dalam suatu organisasi dengan tujuan memberikan perlindungan entitas dan tindakan yang tidak sesuai dengan peraturan yang berlaku (Yulian et al., 2017). Kurang efektifnya sistem pengendalian inernal dan memicu kesempatan terjadi kecurangan di suatu organisasi. Pengendalian internal yang semakin ditingkatkan dengan baik maka dapat meminimalisir terjadinya kesempatan dalam berbuat curang yang dapat merugikan pihak lain. . Pengendalian internal yang diterapkan rendah dan kepatuhan karyawan terhadap pengendalian internal yang juga rendah dapat menjadi pemicu terjadinya kecurangan. Penelitian yang dilakukan oleh Putra \& Latrini (2018), Udayani \& Sari (2017), Atmadja \& Saputra (2017), Dewi et al (2017) menyatakan pengendalian internal berpengaruh negatif terhadap kecenderungan kecurangan akuntansi.

Adanya pengendalian internal yang baik, diharapkan setiap bentuk dan tindakan kesalahan maupun kecurangan yang akan atau sedang terjadi di 
lembaga keuangan dapat dikurangi atau dapat dicegah sedini mungkin agar tidak merugikan pihak lain. Semakin baik pengendalian internal yang diterapkan oleh lembaga keuangan maka semakin rendah tingkat kecurangan yang terjadi karena karyawan telah menaati seluruh aturan maupun serangkaian proses sudah diimplementasikan dengan baik untuk memperoleh keyakinan mengenai keandalan pelaporan keuangan.

$\mathrm{H}_{1}$ : Pengendalian internal berpengaruh negatif pada kecenderungan kecurangan akuntansi .

Sejalan dengan teori fraud of triangle menjelaskan bahwa kecurangan dilakukan oleh seseorang karena tiga dorongan atau penyebab diantaranya rasionalisasi. Sifat atau nilai etis yang mengizinkan berperilaku tidak jujur oleh manajemen dan karyawan atau keadaan yang tertekan sehingga berada di lingkungan yang tidak jujur merupakan pengertian dari rasionalisasi. Budaya organisasi ditanamkan di organisasi untuk mendorong seseorang melakukan tindakan sesuai etika. Lingkungan etis membuat karyawan cenderung bertindak atau menjalankan peraturan sesuai dengan norma dan menghindari kecurangan dalam organisasi (Lestari et al., 2015).

Hasil penelitian oleh Lestari et al (2015), Domnisoru et al (2017), Putra \& Latrini (2018), Lestari et al (2015), Arnila et al (2018) menyatakan bahwa budaya etis organisasi berpengaruh negatif terhadap fraud. Budaya organisasi yang kuat dapat mendorong anggota organisasi untuk melakukan suatu tindakan dengan aturan dan norma yang disepakati oleh organisasi untuk mencapai tujuan organisasi dan meminimalisir terjadinya kecurangan. Semakin kuat budaya organisasi yang diterapkan maka dapat meminimalisir terjadinya kecurangan dalam organisasi.

$\mathrm{H}_{2}$ : Budaya organisasi berpengaruh negatif pada kecenderungan kecurangan akuntansi.

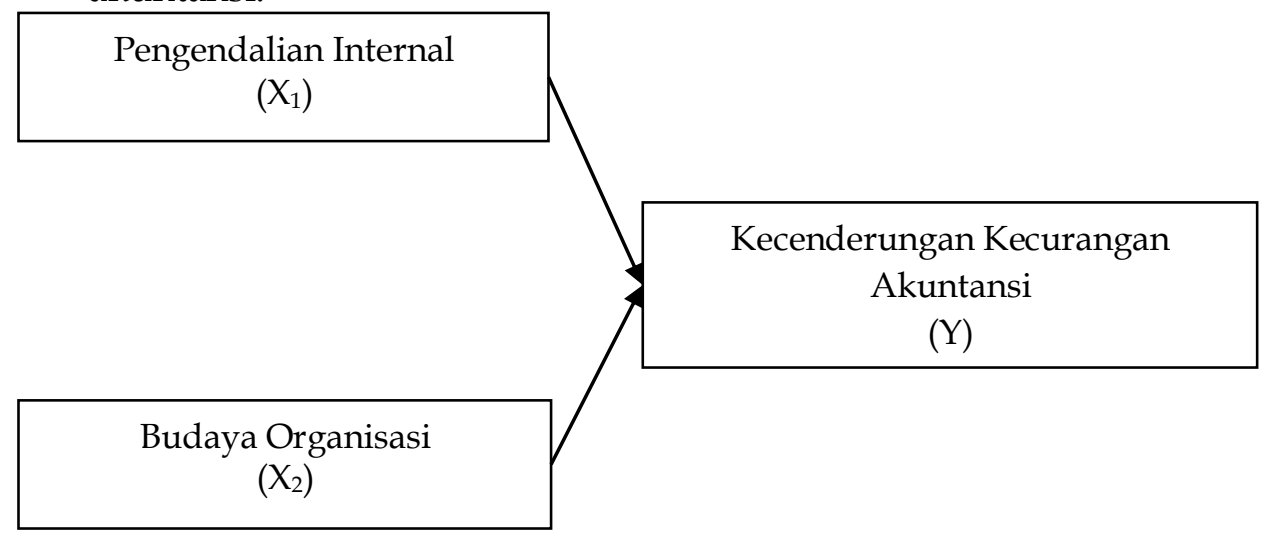

Gambar 1. Model Peneltian

Sumber: Data Penelitian, 2019

\section{METODE PENELITIAN}

LPD Kabupaten Tabanan merupakan lokasi penelitian ini. Pemilihan lokasi dalam penelitian ini karena adanya fenomena atau kasus kecurangan yang terjadi di beberapa LPD di Kabupaten Tabanan. 
Kecenderungan untuk melakukan manipulasi, pemalsuan, atau perubahan catatan akuntansi atau dokumen pendukungnya; Kecenderungan untuk melakukan penyajian yang salah atau penghilangan peristiwa, transaksi, atau informasi yang signifikan dari laporan keuangan; Kecenderungan untuk melakukan salah dalam menerapkan prinsip akuntansi secara sengaja; Kecenderungan untuk melakukan penyajian laporan keuangan yang salah akibat pencurian (penyalahgunaan atau penggelapan) terhadap aktiva yang membuat entitas membayar barang atau jasa yang tidak diterima; Kecenderungan untuk melakukan penyajian laporan keuangan yang salah akibat perlakuan yang tidak semestinya terhadap aktiva dan disertai dengan catatan atau dokumen palsu dan menyangkut satu atau lebih individu di antara manajemen, karyawan atau pihak ketiga dalam penelitian ini sebagai indicator yang digunakan sebagai proksi pada variabel kecenderungan kecurangan akuntansi.

Tujuan dapat dicapai oleh suatu organisasi secara efektif dan efisien apabila pengendalian internal dapat berjalan efektif dan dipatuhi oleh karyawan (Putri \& Irwandi, 2016). Pengendalian internal diukur menggunakan 5 indikator yaitu lingkungan pengendalian, penilaian risiko, aktivitas pengendalian, informasi dan komunikasi, dan pemantauan

Indikator yang digunakan sebagai alat ukur dari variabel budaya organisasi dalam penelitian ini yaitu odel peran yang visible, komponen harapan etis, pelatihan etis, hukuman bagi tindakan etis, dan mekanisme perlindungan etika.

Penelitian ini menggunakan populasi LPD Kabupaten Tabanan sejumlah 304 LPD. Sampel berjumlah 31 LPD dengan 93 responden. Responden dalam penelitian ini adalah ketua, bendahara, dan badan pengawas LPD di Kabupaten Tabanan. Teknik penentuan sampel dalam penelitian ini adalah teknik probability sampling dengan proportionate stratified random sampling menggunakan rumus Slovin dengan tingkat kesalahan yang diharapkan adalah sebesar 10 persen atau 0,1 .

Kuesioner dan observasi pada penelitian ini digunakan sebagai metode merupakan pengumpulan data. Pertanyaan atau pernyataan tertulis diberikan kepada responden untuk dijawab dalam teknik pengumpulan data merupakan pengertian dari kuesioner (Sugiyono, 2017: 225). Skala Likert modifikasi digunakan dalam mengukur hasil jawaban responden. Observasi merupakan teknik pengumpulan data yang digunakan bila penelitian berkenaan dengan perilaku manusia, proses kerja, gejala-gejala alam dan bila responden yang diamati tidak terlalu besar (Sugiyono, 2017;235). Dalam rangka mendapatkan keakuratan mengenai data yang dikumpulkan maka dilakukan uji instrumen. Tahapan analisis data dalam penelitian ini yaitu: uji asumsi klasik dilakukan dalam penelitian ini yaitu uji normalitas, uji multikolinearitas, uji heteroskedastisitas, analisis statistik deskriptif, teknik analisis data yang digunakan dalam penelitian ini adalah analisis regresi linier berganda. Ketepatan dari fungsi regresi sampel dalam menaksir nilai actual diukur dari goodness of fitnya (Gozali, 2016) yang dapat dilihat dari nilai koefisien determinasi $\left(R^{2}\right)$, nilai statistic F (uji kelayakan model), dan nilai statistic $\mathrm{t}$ (uji statistic parameter individual). Rumus Persamaan Regresi Linier Berganda sebagai berikut.

$Y=\alpha+\beta_{1} X_{1}+\beta_{2} X_{2}+\varepsilon$ 


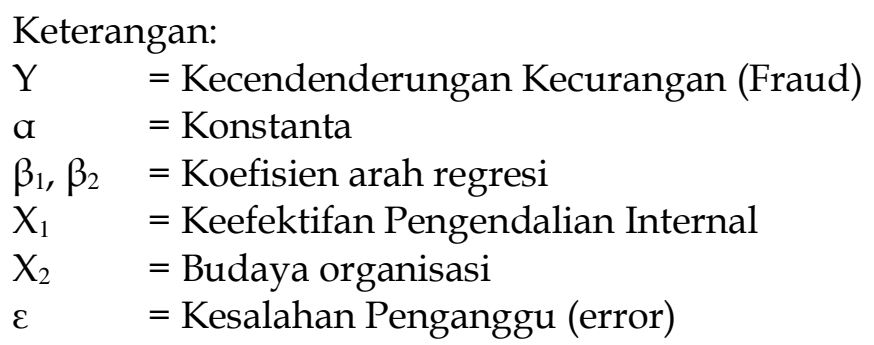

\section{HASIL DAN PEMBAHASAN}

Sampel yang digunakan dalam penelitian ini berjumlah 31 LPD dengan 93 responden di LPD Kabupaten Tabanan. Pengambilan sampel dalam penelitian ini dengan teknik probability sampling dengan proportionate stratified random sampling dengan menggunakan rumus Slovin. Setiap LPD diberikan masingmasing tiga kuesioner yang diisi oleh ketua, bendahara, dan badan pengawas LPD. Ketua LPD dipilih sebagai responden penelitian dikarenakan ketua LPD yang bertanggung jawab atas pengelolaan LPD dan bertanggung jawab dalam menjamin penerapan tata kelola yang baik. Badan Pengawas LPD dipilih sebagai responden dikarenakan badan pengawas bertanggung jawab dalam mengawasi pengelolaan LPD. Bendahara LPD dipilih menjadi responden karena bendahara mengetahui aliran kas masuk dan aliran kas keluar dalam pembukuan. Pengiriman kuesioner dilakukan dengan cara datang dan memberikannya secara langsung kepada 93 responden LPD di Kabupaten Tabanan.Penelitian ini menggunakan sampel sebanyak 31 LPD dengan 93 responden di LPD Kabupaten Tabanan. Penyebaran kuesioner dilakukan 26 hari yaitu mulai tanggal 1 November 2019 sampai dengan 27 November 2019.

\section{Tabel 2. Rincian dan Pengiriman dan Pengambilan Kuesioner}

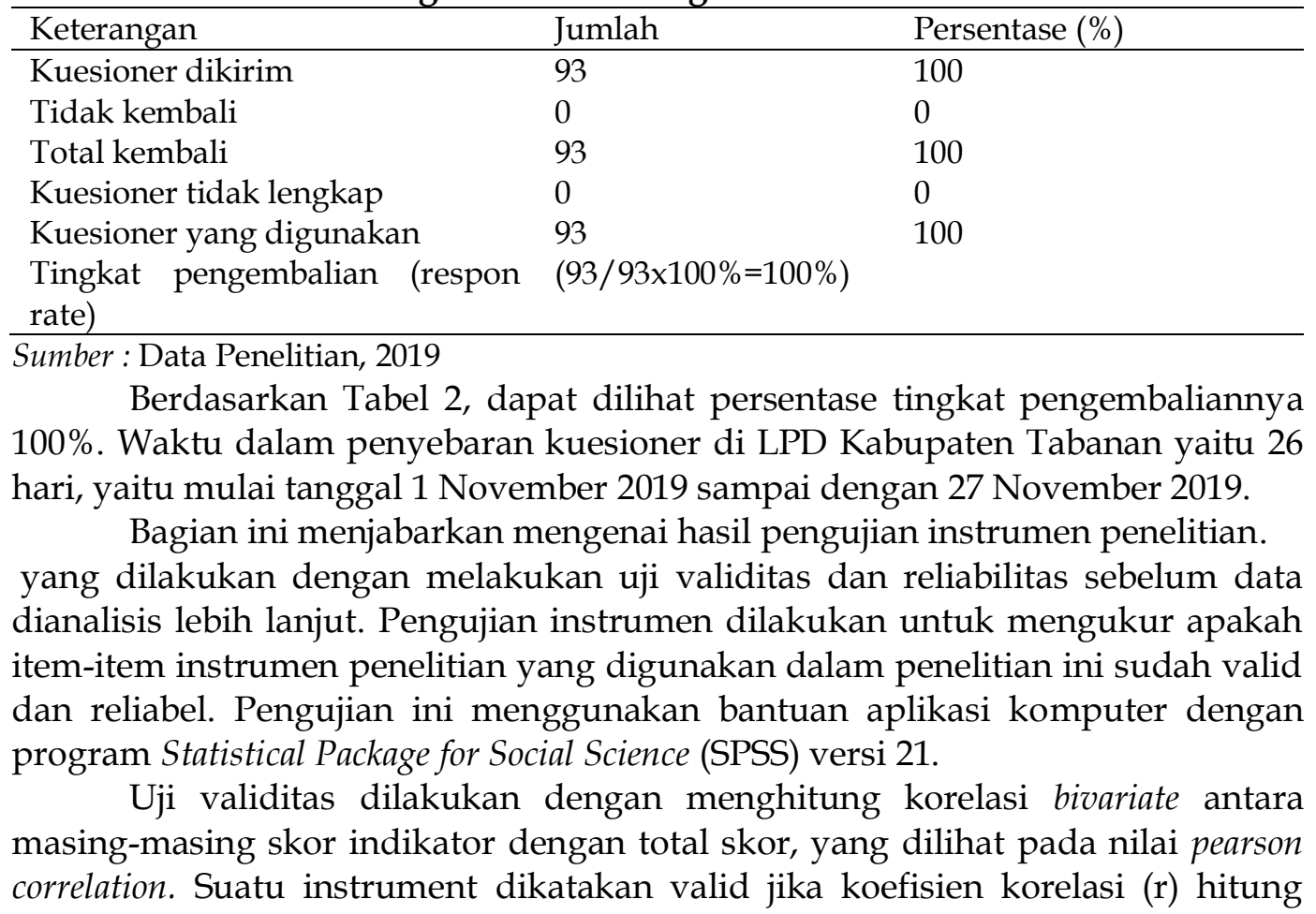


lebih besar dari 0,30 ( $\mathrm{r}>30)$, sedangkan jika $\mathrm{r}$ hitung lebih kecil dari 0,30 maka butir pertanyaan atau pernyataan dinyatakan tidak valid. Hasil uji validitas dapat dilihat pada tabel 4.3 sebagai berikut.

\section{Tabel 3. Hasil Uji Validitas}

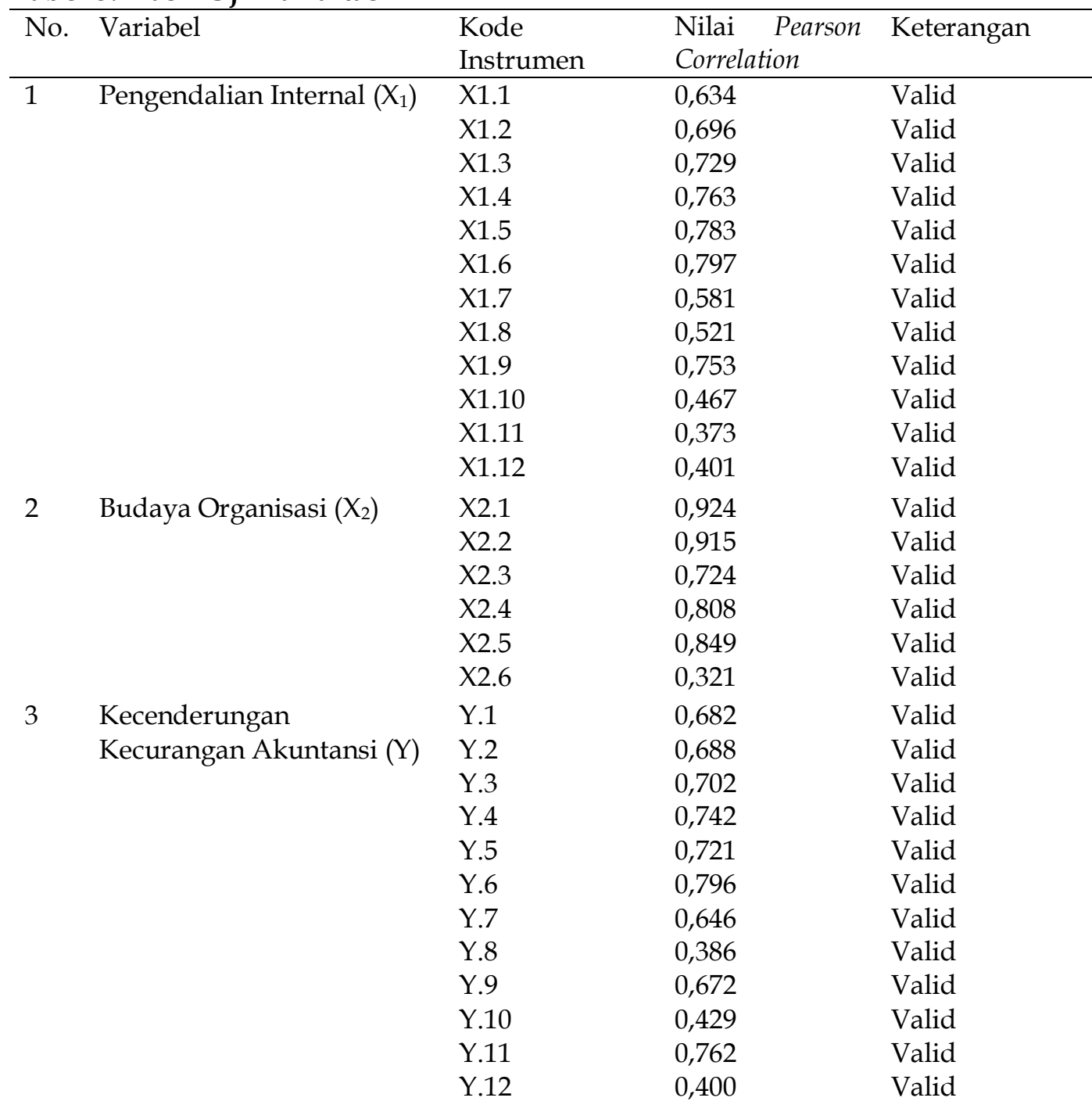

Sumber: Data penelitian, 2019

Pengendalian internal $\left(X_{1}\right)$, budaya organisasi $\left(X_{2}\right)$, dan kecenderungan kecurangan akuntansi $(\mathrm{Y})$ memiliki nilai person correlation positif dan nilainya melebihi 0,30 sehingga semua indikator pernyataan tersebut telah memenuhi syarat validitas data.

\section{Tabel 4. Hasil Uji Reliabilitas}

\begin{tabular}{llll}
\hline No. & Variabel & $\begin{array}{l}\text { Cronbach's } \\
\text { Alpha }\end{array}$ & Keterangan \\
\hline 1 & Pengendalian Internal $\left(\mathrm{X}_{1}\right)$ & 0,877 & Reliabel \\
2 & Budaya Organisasi $\left(\mathrm{X}_{2}\right)$ & 0,856 & Reliabel \\
3 & Kecenderungan & 0,824 & Reliabel \\
& keceruangan akuntansi $(\mathrm{Y})$ & &
\end{tabular}

Sumber: Data Penelitian, 2019 
Berdasarkan Tabel 4. nilai cronbach's alpha melebihi nilai 0,60 sehingga dapat dikatakan bahwa semua butir pernyataan atau pertanyaan pengendalian internal $\left(X_{1}\right)$, budaya organisasi $\left(X_{2}\right)$ dan kecenderungan kecurangan akuntansi $(Y)$ tersebut reliabel dan layak dijadikan instrumen penelitian.

Uji asumsi klasik dilakukan untuk meyakinkan bahwa model regresi yang dibuat Uji Normalitas bertujuan untuk menguji apakah residual dari model regresi yang dibuat telah valid, sehingga model layak diteliti dan dapat dianalisis dengan baik. Dalam menguji residual model regresi yang dibuat berdistribusi normal merupakan tujuan dari uji normalitas. Koefisien Asymp. Sign. (2-tailed) lebih besar dari $\alpha=0,05$ (Ghozali, 2016:157) menunjukan data populasi berdistribusi normal.

Tabel 5. Hasil Uji Normalitas

Unstandardized Residual

\begin{tabular}{ll}
\hline $\mathrm{N}$ & 93 \\
Kolmogorov-Smirnov Z &, 847 \\
Asymp. Sig. (2-tailed) &, 470 \\
\hline
\end{tabular}

Sumber: Data Penelitian, 2019

Dilihat pada tabel 5 nilai signifikansi sebesar 0,642 > 0,05 maka dapat diterik kesimpulan bahwa persamaan regresi berdistribusi normal.

Tujuan uji multikolinearitas yaitu apakah ditemukan korelasi antar variabel pada model regresi. Multikolinearitas tidak ada jika nilai tolerance lebih dari 10 persen dan VIF kurang dari 10 homogeny (Suyana Utama,2016:111).

Tabel 6. Hasil Uji Multikolinaritas

\begin{tabular}{lccl}
\hline Variabel & \multicolumn{2}{c}{ Collinearity Statistics } & Keterangan \\
\cline { 2 - 3 } & Tolerance & VIF & \\
\hline (Constant) & & & \\
$\mathrm{X}_{1}$ & 0,992 & 1,008 & Bebas Multikolinearitas \\
$\mathrm{X}_{2}$ & 0,992 & 1,008 & Bebas Multikolinearitas \\
\hline
\end{tabular}

Sumber: Data Penelitian, 2019

Berdasarkan Tabel 6 menunjukan nilai tolerance variabel $X_{1}$ dan $X_{2}$ melebihi 10 persen $(0,10)$ dan nilai VIF lebih kecil dari 10 sehingga dapat disimpulkan bahwa tidak ada multikolinaritas dalam model regresi antar variabel independen.

Uji heteroskedastisitas bertujuan untuk menguji apakah dalam model regresi terjadi ketidaksamaan varians dari residual satu pengamatan ke pengamatan lain (Suyana Utama, 2016:112). Nilai signifikansi variabel bebas terhadap nilai absolute residual lebih besar dari $a=0,05$, jika tidak mengandung heteroskedastisitas.

Tabel 7. Hasil Uji Heteroskedastisitas

\begin{tabular}{ccl}
\hline Variabel & Sig. & Keterangan \\
& & \\
\hline Pengendalian Internal $\left(X_{1}\right)$ & 0,070 & Bebas Heteroskedastisitas \\
Budaya Organisasi $\left(X_{2}\right)$ & 0,850 & Bebas Heteroskedastisitas \\
\hline
\end{tabular}

Sumber: Data Penelitian, 2019 
Tabel 7. Menunjukan nilai signifikansi dari variabel $X_{1}$ dan $X_{2}$ lebih besar dari 0,05, sehingga dapat disimpulkan bahwa seluruh variabel tersebut terbebas dari gejala heteroskedastisitas.

Tabel 8. Hasil Analisis Statistik Deskriptif

\begin{tabular}{lcclcl}
\hline Variabel & $\mathrm{N}$ & Minimum & Maximum & Mean & $\begin{array}{l}\text { Std. } \\
\text { Deviation }\end{array}$ \\
\hline Pengendalian Internal $\left(\mathrm{X}_{1}\right)$ & 93 & 21.30 & 43.91 & 31.1511 & 5.35684 \\
Budaya organisasi $\left(\mathrm{X}_{2}\right)$ & 93 & 9.34 & 24.15 & 18.3341 & 2.88003 \\
$\begin{array}{l}\text { Kecenderungan Kecurangan } \\
\text { Akuntansi }(\mathrm{Y})\end{array}$ & 93 & 12.00 & 31.87 & 20.4143 & 5.66875 \\
Valid N (listwise) & 93 & & & &
\end{tabular}

Sumber: Data Penelitian, 2019

Nilai minimum dan nilai maksimum variabel pengendalian internal dalam analisis statistik deskriptif 21.30 dan 43.91. 31.1511 merupakan nilai ratarata pengendalian internal dan masuk dalam kategori skala > 26.9525 sampai dengan 32.605 hal ini menandakan sistem pengendalian internal yang buruk. Variabel budaya organisasi memiliki nilai minimum sebesar 9.34 dan nilai maksimum 24.15. nilai rata-rata dari budaya organisasi yaitu sebesar 18.3341 masuk dalam kategori skala > 16.745 sampai dengan 20.4475 hal ini menandakan budaya organisasi baik. Variabel kecenderungan kecurangan akuntansi memiliki nilai mininum 12.00 dan nilai maksimum 31.87. Nilai rata-rata dari kecenderungan kecurangan akuntansi yaitu sebesar 20.4143 masuk kategori skala $>16.9675$ sampai dengan 21.935 hal ini menandakan kecurangan akuntansi buruk..

Tabel 9. Hasil Uji Regresi Linear Berganda

\begin{tabular}{|c|c|c|c|c|c|c|}
\hline \multirow[t]{2}{*}{ Model } & & \multicolumn{2}{|c|}{ Unstandardized Coefficients } & \multirow{2}{*}{$\begin{array}{c}\begin{array}{c}\text { Standardized } \\
\text { Coefficients }\end{array} \\
\text { Beta }\end{array}$} & \multirow[t]{2}{*}{$\mathrm{t}$} & \multirow[t]{2}{*}{ Sig. } \\
\hline & & $B$ & Std. Error & & & \\
\hline & (Constant) & 38.992 & 4.028 & & 9.679 & .000 \\
\hline 1 & $\mathrm{X} 1$ & -.450 & .100 & -.425 & -4.498 & .00 \\
\hline & $\mathrm{X} 2$ & -.168 & .082 & -.192 & -2.037 & .045 \\
\hline
\end{tabular}

Sumber: Data Penelitian, 2019

Nilai konstanta (a) bertanda positif sebesar 38,992 berarti bahwa pengendalian internal $\left(X_{1}\right)$ dan budaya organisasi $\left(X_{2}\right)$ memiliki nilai konstan, nilai kecenderungan kecurangan akuntansi $(Y)$ meningkat. Nilai $\beta_{1}$ untuk variabel pengendalian internal sebesar $-0,450$ berarti apabila variabel pengendalian internal meningkat, maka akan mengakibatkan kecenderungan kecurangan akuntansi menurun dengan asumsi faktor lainnya konstan. Nilai $\beta_{2}$ untuk variabel budaya organisasi sebesar $-0,168$ berarti apabila variabel budaya organisasi meningkat, maka akan mengakibatkan kecenderungan kecurangan akuntansi menurun dengan faktor lainnya konstan.

Pengujian koefisien determinasi $\left(R^{2}\right)$ menyatakan variabilitas variabel dependen yaitu kecenderungan kecurangan akuntansi dijelaskan melalui variabilitas variabel independen yaitu pengendalian internal dan budaya 
organisasi sebesar 0,186 hal ini berarti bahwa 18,6 persen, sedangkan sisanya 81,4 persen variabilitas pada variabel dependen dijelaskan oleh faktor-faktor lain di luar variabel independen yang digunakan pada penelitian.

Pengujian kelayakan model (uji F) digunakan untuk menguji apakah variabel bebas yang digunakan dalam penelitian ini secara simultan memiliki pengaruh terhadap variabel terikat. Berdasarkan hasil pengolahan data dengan program Statistical Package for Social Science (SPSS) nilai signifikansi $\mathrm{F}=0,000$ $<a l p h a=0,05$ dengan nilai $\mathrm{F}$ hitung sebesar 11,483. Hal ini berarti model yang digunakan dalam penelitian ini adalah layak atau variabel bebas mampu menjelaskan variabel terikat.

Pada hasil perhitungan didapat nilai signifikansi $t=0,000<0,005$ dengan nilai beta sebesar -0,450 sehingga dapat disimpulkan bahwa $\mathrm{H}_{1}$ diterima. Dengan hasil tersebut dapat ditarik kesimpulan bahwa pengendalian internal memiliki pengaruh negatif pada kecenderungan kecurangan akuntansi. Nilai signifikansi $t$ $=0,045<0,005$ sedangkan nilai beta sebesar $-0,168$ sehingga $\mathrm{H}_{2}$ diterima yang berarti bahwa budaya organisasi memiliki pengaruh negatif pada kecenderungan kecurangan akuntansi.

Hipotesis pertama $\left(\mathrm{H}_{1}\right)$ menyatakan bahwa pengendalian internal berpengaruh negatif pada kecenderungan kecurangan akuntansi. Berdasarkan hasil pengujian hipotesis dengan menggunakan regresi linier berganda menunjukan bahwa pengendalian internal berpengaruh negatif pada kecenderungan kecurangan akuntansi di LPD Kabupaten Tabanan, sehingga hipotesis pertama diterima. Pengendalian internal di LPD Kabupaten Tabanan semakin ditingkatkan agar kecenderungan kecurangan akuntansi dapat diminimalisir. Hasil penelitian ini sejalan dengan hasil penelitian Udayani \& Sari (2017), Atmadja \& Saputra (2017), Dewi dkk (2017) menyatakan pengendalian internal berpengaruh negatif pada kecenderungan kecurangan (fraud) akuntansi.

Penelitian ini memiliki hasil yang mendukung teori fraud triangle dimana terdapat tiga faktor penyebab seseorang melakukan kecurangan akuntansi salah satunya yaitu kesempatan (opportunity). Kecurangan secara diam-diam yang dilakukan oleh individu dalam suatu kondisi tertentu disebut dengan peluang. Adanya kesempatan merupakan alasan mengapa pelaku melakukan kecurangan dengan leluasa. Pengendalian internal semakin baik dan ditingkatkan, maka akan mengurangi peluang yang mendorong tindakan kecurangan akuntansi tersebut terjadi.

Hipotesis kedua $\left(\mathrm{H}_{2}\right)$ menyatakan bahwa budaya organisasi berpengaruh negatif pada kecenderungan kecurangan akuntansi. Berdasarkan hasil uji hipotesis dengan menggunakan regresi linier berganda menunjukan bahwa budaya organisasi berpengaruh negatif pada kecenderungan kecurangan akuntansi di LPD Kabupaten Tabanan, sehingga hipotesis kedua diterima. Semakin diperkuat budaya organisasi di LPD Kabupaten Tabanan, maka kecenderungan kecurangan akuntansi yang terjadi berkurang. Hasil penelitian ini sejalan dengan penelitian Putra \& Latrini (2018), Lestari dkk (2015), Arnila dkk (2018) memiliki hasil penelitian yaitu budaya organisasi memiliki pengaruh negatif pada kecenderungan kecurangan akuntansi. Dewi \& Wirakusuma (2019) mendapat hasil yang sama yaitu budaya etis organisasi berpengaruh negatif pada kecenderungan kecurangan akuntansi. 
Teori fraud triangle didukung oleh hasil penelitian ini yaitu menjelaskan tiga faktor penyebab seseorang melakukan tindakan kecenderungan kecurangan akuntansi, salah satunya yaitu rasionalisasi (rasionalization). Faktor rasionalisasi menjelaskan bahwa sikap, karakter, atau serangkaian nilai-nilai etis yang memperbolehkan pegawai melakukan tindakan yang tidak jujur, atau mereka berasa dalam lingkungan yang tidak jujur. Diterapkannya budaya organisasi yang baik akan mengurangi terjadinya faktor rasionalisasi seperti merasionalisasikan tindakan kecurangan akuntansi.

Implikasi teoritis penelitian ini memberikan pengaruh pengendalian internal dan budaya organisasi pada kecenderungan kecurangan akuntansi di LPD Kabupaten Tabanan. Hasil uji penelitian ini menemukan bahwa kedua variabel independen yakni pengendalian internal serta budaya organisasi memiliki pengaruh negatif pada kecenderungan kecurangan akuntansi. Hasil penelitian ini sesuai dengan teori fraud triangle. Penelitian ini mampu menambah informasi dan pengetahuan mengenai pentingnya pengendalian internal ditingkatkan dan budaya organisasi diperkuat dalam meminimalisir terjadinya kecurangan di LPD Kabupaten Tabanan. Implikasi praktis penelitian ini yaitu memberikan masukan bagi LPD di Kabupaten Tabanan khususnya badan pengawas LPD dalam memahami tata cara pengawasan serta mengadakan pelatihan badan pengawas LPD sekabupaten Tabanan, dengan pelatihan ini diharapkan pengawasan LPD dapat dilakukan dengan efektif setelah memahami tata cara pengawasan.

\section{SIMPULAN}

Kesimpulan pada penelitian ini yaitu pengendalian internal serta budaya organisasi memiliki pengaruh negatif pada kecenderungan kecurangan akuntansi di LPD Kabupaten Tabanan di mana hal tersebut berarti semakin baik pengendalian internal dan budaya organisasi maka tingkat kecenderungan kecurangan akuntansi di LPD Kabupaten Tabanan akan semakin menurun. Saran mngacu pada statistik deskriptif, bagi LPD di Kabupaten Tabanan mohon diperhatikan agar pengendalian internal ditingkatkan agar semakin baik dan budaya organisasi diperkuat agar semakin baik serta kecurangan di LPD Kabupaten Tabanan buruk menurut analisis statistic deskriptif maka dari itu dimohonkan peran badan pengawas LPD lebih ditingkatkan dalam membantu meminimalisir adanya kecenderungan kecurangan akuntansi. Penggunaan sampel yang berada di kabupaten lain merupakan saran bagi peneliti selanjutnya yang ingin melakukan penelitian sejenis sehingga variabel penelitian dapat tergambarkan dengan baik serta menambah variabel-variabel lain yang berpengaruh terhadap kecenderungan kecurangan akuntansi seperti variabel kejujuran pengurus.

\section{REFERENSI}

Akbar, A. G. (2019). The Impact of a Procurement Implementation and Government Internal Control System on Goods/Services Procurement Fraud Prevention by Using Organization Ethical Culture as a Moderating Variable. Jurnal Economia, 15(1), 69-81. https://doi.org/10.21831/economia.v15i1.23618 
Aprilliyanti, W., \& Fitri, Y. (2018). Pengaruh Keefektifan Pengendalian Internal, Asimetri Informasi, Budaya Etis Organisasi dan Keadilan Prosedural Terhadap Kecenderungan Kecurangan (Fraud) Pada Pemerintah Kota Kendari. 121.

Arnila, T., Basri, Y. M., \& Desmiyawati. (2018). Pengaruh Keefektifan Pengendalian Internal, Komitmen Organisasi, Budaya Etis Organisasi Dan Ketaatan Aturan Akuntansi Terhadap Fraud (Studi Empiris Pada Organisasi Perangkat Daerah Kabupaten Siak). Jurnal Online Mahasiswa, 1.

Atmadja, A. T., \& Saputra, K. A. K. (2017). Pencegahan Fraud dalam Pengelolaan Keuangan Desa. 1, 7-16.

Chandrayatna, I. D. G. P., \& Sari, M. M. R. (2019). Pengaruh Pengendalian Internal, Moralitas Individu Dan Budaya Etis Organisasi Pada Kecenderungan Kecurangan Akuntansi. 27, 1063-1093.

Dana LPD Desa Adat Belumbang Rp 1,3 Miliar Diselewengkan. (2018). Retrieved from BALI TRIBUNE website: balitribune.co.id

Dana LPD Kota Tabanan Menguap, Nasabah Bingung, Manajer Menghilang. (2018). Retrieved from BALI EXPRESS, TABANAN website: baliexpress.co.id

Dewi, N. K. A. A., \& Wirakusuma, M. G. (2019). Pengaruh Moralitas Individu, Pengendalian Intern Dan Budaya Etis Organisasi Terhadap Kecenderungan Kecurangan Akuntans. E-JA e-Jurnal Akuntansi, 28(3), 1667-1681.

Dewi, N. M. D. martini, Yuniarta, G. A., \& Wahyuni, M. A. (2017). Pengaruh pengendalian internal, budaya etis organisasi, dan kesesuaian kompensasi terhadap kecenderungan kecurangan (fraud) akuntansi pada koperasi simpan pinjam di Kabupaten Jembrana. Akuntansi Program S1, 8 no 2(1).

Domnisoru, S., Ogarca, R., \& Dragomir, I. (2017). Organizational culture and $\begin{array}{llll}\text { internal control. Audit Financiar, } & \text { 15(148), }\end{array}$ https://doi.org/10.20869/auditf/2017/148/628

Gozali, I. (2016). Aplikasi Analisis Multivariete dengan Program IBM SPSS 21. Semarang: Badan Penerbit Universitas Diponegoro.

Indrijawati, A., Nichen, \& Kartini. (2019). The Tendency of Accounting Fraud in Mediation Influence Of Internal Control and Information Asymmetry on Organizational Accountability. 8(April), 1-10.

Julyana. (2015). Pengaruh Pengendalian Internal, Kepuasan Kerja, Moralitas Manajemen, dan Budaya Etis Organisasi Terhadap Kecenderungan Kecurangan Akuntansi. 11, 135-144.

Laffin, M., \& Gomes, T. (2013). The Prevention of Error and Fraud in Accounting. International Journal of Advances in Management and Economics, 125-131.

Lestari, K. A., Purnamawati, I. G. A., \& Herawati, N. T. (2015). Pengaruh Pengendalian Internal dan Budaya Etis Organisasi terhadap Kecenderungan Kecurangan (Fraud ) Pada Koperasi Simpan Pinjam di Kecamatan Buleleng. E-Journal S1 Ak Universitas Pendidikan Ganesha, 3(1), 11.

Lubis, A. I. (2009). Akuntansi Keperilakuan Edisi 2 (2nd ed.). Salemba Empat.

Nahartyo, E., \& Haryono. (2018). Magnitude of Corruption, Rationalization, and Internal Control Quality: an Experimental Study on Subsequent Offense. Jurnal Akuntansi Dan Keuangan Indonesia, 15(2), 164-179. https:// doi.org/10.21002/jaki.2018.09

Nurlaeliyah, S., \& Anisykurlillah, I. (2017). Analysis of Factors Affecting The 
Tendency of Accounting Fraud with An Ethical Behavior As Intervening Variable. Accounting Analysis Journal, 6(2), 299-312. https:// doi.org/10.15294/aaj.v6i2.16892

Ocansey, E. O. N. ., \& Josephine Ganu, P. (2017). The Role of Corporate Culture in Managing Occupational Fraud. Research Journal of Finance and Accounting, $8(24), 2222-2847$.

Okoye, P., \& Nwoka, E. (2019). Forensic Accounting And Fraud Prevention in Manufacturing Companies in Nigeria. International Journal of Innovative Finance and Economics Research, 7(1), 107-116.

Omar, N., Johari, Z. A., \& Hasnan, S. (2015). Corporate Culture and the Occurrence of Financial Statement Fraud: A Review of Literature. Procedia Economics and Finance, 31(15), 367-372. https://doi.org/10.1016/s22125671(15)01211-3

Prof. Dr. Made Suyana Utama, SE., M. (2016). Aplikasi Analisis Kuantitatif. cv.sastra utama.

Putra, I. P. A. P. E., \& Latrini, M. Y. (2018). Pengaruh Pengendalian Internal, Budaya Organisasi, dan Moralitas pada Kecenderungan Kecurangan (Fraud) di Lpd Se-Kabupaten Gianyar. E-Jurnal Akuntansi, 53(25). Retrieved from https:/ / doi.org/10.24843/EJA.2018.v25.i03.p20

Putri, P. A. A., \& Irwandi, S. A. (2016). The Determinants of Accounting Fraud Tendency. The Indonesian Accounting Review, 6(1), 99. https:// doi.org/10.14414/tiar.v6i1.857

Rivera, E. (2018). Detect Fraud, Improve Internal Control Using Popular Strategy, Performance Tool. Retrieved from www.intosaijournal.org

Said, J., Alam, M. M., \& Karim, Z. A. (2017). Integrating Religiosity into Fraud Triangle Theory; findings on Malaysian Police Officers. Journal of Chemical Information and Modeling, 53(9), 1689-1699. https:// doi.org/10.1017/CBO9781107415324.004

Setiawan, S. (2018). the Effect of Internal Control and Individual Morality on the Tendency of Accounting Fraud. Asia Pacific Fraud Journal, 3(1), 33. https://doi.org/10.21532/apfj.001.18.03.01.04

Sugiyono. (2017). Metode Penelitian: Kuantitatif, Kualitatif, dan $R \mathcal{E}$ D. Bandung: Alfabeta Bandung.

Udayani, A. A. K. F., \& Sari, M. M. R. (2017). Pengaruh Pengendalian Internal dan Moralitas Individu pada Kecenderungan Kecurangan Akuntansi. EJurnal Akuntansi Universitas Udayana, 18, 1774-1799.

Umar, H., Indriani, A., \& Purba, R. B. (2019). The Determinant Fraud Prevention of Quality Local Government'S Financial Report. Jurnal Akuntansi Dan Bisnis : Jurnal Program Studi Akuntansi, 5(1), 41. https:// doi.org/10.31289/jab.v5i1.2310

Widilestariningtyas, O., \& Karo, R. S. K. (2016). The Influence of Internal Audit and Internal Control on Fraud Prevention in Bandung Regency Government. Journal of Administrative and Business Studies, 2(3), 143-150. https:// doi.org/10.20474/jabs-2.3.5

Yulian, A. P., Herwanti, R. T., \& Pituringsih, E. (2017). Influence the Suitability of Compensation, Internal Control Systems, Leadership and Organizational Culture to The Tendency of The Accounting Fraud at Work Unit ( Skpd ) 
Bima Local Government. International Conference and Call for Papers, Jember, 1575-1598.

Zelmiyanti, R., \& Anita, L. (2015). Pengaruh Budaya Organisasi dan Peran Auditor Internal Terhadap Pencegahan Kecurangan dengan Pelaksanaan Sistem Pengendalian Internal Sebagai Variabel Intervening. Jurnal Akuntansi Keuangan Dan BIsnis, 8(10), 67-76. 